\title{
Adult Education for Meaningful Socio-Economic Development in Nigeria
}

\author{
Dr. Mbalisi Onyeka Festus (Corresponding Author) \\ Department of Adult \& Non-Formal Education, Faculty of Education, University of Port \\ Harcourt, Pmb 5323 Choba, Portharcourt, Rivers State, Nigeria \\ Tel: 234-806-418-4036. E-mail: onyipath@yahoo.com; onyeka.mbalisi@uniport.edu.ng \\ Dr. Oyebamiji Morufu Adekola (Reader) (Corresponding Author) \\ Department of Adult \& Non-Formal Education, Faculty of Education, University of Port \\ Harcourt, Pmb 5323 Choba, Portharcourt, Rivers State, Nigeria
}

Tel: 234-803-3515-091. E-mail: morufu.oyebamiji@uniport.edu.ng

Received: December 22, 2014 Accepted: June 7, 2015 Published: June 11, 2015

doi:10.5296/jsss.v2i2.7799 URL: http://dx.doi.org/10.5296/jsss.v2i2.7799

\begin{abstract}
This paper establishes adult education as an indispensable tool for the achievement of meaningful socio-economic development of any nation. The paper identified different dimensions of development as well as various phenomena and their resultant effects which constitute a bane to successful socio-economic development in Nigeria. It proposes adult education programmes relevant for the development of a literate, informed, skilled and healthy adult population that drives successful socio-economic development activities. It concludes that adult education programmes are veritable tools designed to equip adults who are the economically productive and active citizens with required knowledge, attitudes, skills and commitment needed for meaningful socio-economic development.
\end{abstract}

Keywords: Adult, Adult education, Development, Socio-Economic development 


\section{Introduction}

The supposed target of every nation is to make life easy, cheap and comfortable for her citizens. It is this intention that drives nations into embarking in many activities some of which are economic, political, social, religious, cultural, technological etc in order to raise the capital base of the nation. It is believed that increase in the capital base will empower the nation to embark on development of infrastructure and production of goods and services that would make life easy, sweet and comfortable. In an ideal society, comfort as a result of improved human well-being is achieved when there is an increase in per capita income, gross domestic (GDP), gross national product (GNP), shift from primary to secondary production, reduced dependence on importation, strong industrial capacity, increased literacy level etc.

In Nigeria, the case is different. Attempts to grow Nigeria's economy has been bedeviled by poor infrastructural facility development and maintenance, dependence on imported goods and services, reliance on a single economic sector, weak industrial capacity, inefficient and ineffective public utilities, low literacy level. These problems constitute a cog in the wheel of Nigeria's economic growth and development and as a result hinder human growth and development and improved human well-being.

This situation calls for adult education programmes that shall be directed towards addressing these problems and challenges facing human beings. Adult education is very vital to addressing these problems because it provides adult with the necessary skills, attitudes, knowledge, values, beliefs required to trigger social and economic development of any society. It is important to target adults because they, rather than children hold the destiny of modern society in their hands (Anyanwu, 1987). In support of Anyanwu's view, Obi (1987) maintains that adults are those who are already working and participating in development efforts. Obi further emphasizes that adult education programmes unlike education for children and adolescents, centre on the immediate needs and problems of the adults in their homes, social and occupational roles, civic and economic interests and therefore have immediate direct positive relationship with development objectives. Since adults are those already participating in development efforts, there is need to develop a skilled and informed population of adults who would be capable of understanding national problems and needs and are able to channel their activities towards the fulfilment of national goals. Skilled and informed adult population is very necessary both for the advancement of social and economic development as well as the promotion of internal unity. This fact makes adult education an indispensable means for the achievement of economic, political and social survival.

\section{The Concept of Adult Education}

The purpose here is not to analyze various definitions of adult education as have been put forward by different scholars. But efforts shall be made to portray adult education as an indispensable tool for socio-economic development required to foster national unity. Accounts have it that adult education emerged out of the need to proffer solutions to myriad of problems caused by and which in turn affect adults in the society. Such problems are ones created by industrial revolution, civil wars and world wars 1 and 11 as well as the society's concern for man's salvation. Adult education was identified during these periods with the task 
of teaching adults how to read so they could attain salvation through the Holy Scriptures. At this point in history, adult education became publicly defined as a discrete field of social practice which serves primarily as an instrument of social reform, social reconstruction and social progress (Schroeder, 1970; Anyanwu, 1987).

Anyanwu (1987) pointed out that the problems generated by the above mentioned events are concerned with change, and it is these problems which adult education is called upon to solve. According to him, its major focus is the dissemination of knowledge, the training of the mind in objective reasoning, and the teaching of skills which may enable the individual to fulfill himself, and to play a full role in the development of the society to which he belongs. Anyanwu quoted Prosser as seeing adult education as a force that generates the energy which is necessary for change. According to him, Prosser defines adult education as:

That force which, in its ideal application, can bring about a maximum of readjustment of attitude within a society to any new and changed situation in the shortest possible time, and which helps to initiate change which evolves and imparts new skills and technique required and made necessary by the change (Anyanwu 1987:18).

A definition considered more balanced, encompassing, comprehensive and elaborate was given by UNESCO in its 1976 Conference. UNESCO according to Bown and Tomori (1979:269) defines adult education as:

The entire body of organized educational process, whatever the content, level and methods, whether formal or otherwise, whether they promote or replace initial education in the schools, colleges or universities as well as in apprenticeship, whereby persons regarded as an adult by the society to which they belong develop their abilities, enrich their knowledge, improve their technical or professional qualifications and bring about changes in their attitude or behaviour in the two fold perspective of full personal development and participation in balanced and independent social, economic and cultural development.

This definition harmonized the various components of patches of definitions that were existed before 1976 and formed the foundation on which various discrete new definitions of adult education are being emanated. For instance, Nzeneri (2008) defines adult education as any education given to adults based on their social, political, cultural and economic needs and problems to enable them adjust fully to changes and challenges in their lives and society. Eheazu (1998:15) sees it as "some specific functional training/vocational programmes required by adults (who now constitute the illiterate, unskilled, semi-skilled or semi-professional labour force) to remedy not only their educational deficiencies but also meet the needs of their various occupations whether as farmers, artisans or employees of corporate/private organizations". He went further to refer to it as any form of alternative education that would re-orientate adults and modify their attitudes in order that they embrace new and progressive ways and actions that would improve their income, living standard and contributions to societal development as well as bring about in them desired changes in their behaviour. Organization for Economic Co-operation and Development in Nnazor (2005: 530) stresses that adult education encompasses all education and training activities undertaken by adults for professional or personal reasons. According to them, it includes general, vocational 
and enterprise based training within a lifelong perspective. Barikor (2002:176-177) defines adult education as:

Any form of educative experience engaged in by people who are chronologically mature, socially responsible and mentally alert or deficient but eager to meet their specific needs. These may include intellectual need, occupational skills, socio-economic responsibilities, professional competencies and even self-fulfillment or self-actualizing needs, to improve themselves, by developing their knowledge, insights, tastes, attitudes and skills.

Adult education according to Mbalisi (2010:59) is "any educative and purposeful learning activity organized for adults to initiate them into a new way of life by providing them with relevant skills, competences, knowledge, information and attitudes required to excel in that aspect of life". Sociologically, Dumazedier in Ezimah (2004:12) defines adult education as:

Action for the cultural development of the society or its component groups; consciously directed towards the development of the economy of society and of the human personality, by means of a system of continuous or recurrent learning which brings the culture and cultural levels which are mostly capable of encouraging such development.

The definitions above reflects inclination of adult education towards solving societal problems, and hence, fostering necessary social change.

\section{The Concept of Development}

Hall (1981) sees development as a steady overall economic growth of a nation together with the steady reduction of gap between the rich and the poor. He stressed that without the concept of equitable distribution of national wealth, economic expansion can only be called growth, not development. It is on this background that Okeke in Okorosaye-Orubite (2005) sees development as "growth plus change", while Okorosaye-Orubite (2005) understands development as "change in a desirable direction and encompassing many different dimensions". Economic, Social and Political developments are part of the dimensions of development from which the concept "Socio-Economic" was coined. Okowa (2005) refer to them as a tripod framework on which the socio-economic formation of any society rests. For a better understanding of the concept, the three distinct concepts from where it is derived shall be briefly explained.

\subsection{Economic Dimension}

This comprises increase in per capita and family income, gross national product, gross domestic product, income distribution, the labour force and job opportunities, housing needs, shift in the labour force from agricultural to industrial and service sectors, rise in energy consumption, expanded use of high technology such as automobile, telephones, television and public transportation (Indabawa \& Mpofu, 2006; Fagerlind \& Saha, 1989; Okediji, 1981; Okorosaye-Orubite, 2005; Akinpelu, 2002).

\subsection{Social Dimension}

This is a democratic process of developing people's capacity to grow socially, culturally, 
economically and politically through the acquisition of new knowledge, attitudes and skills, and through participation in social and political decision-making. It comprises provision of human needs such as food, shelter, quality health delivery system, potable water, safety and security, quality education. It also comprises the non-materialistic values such as respect for the human person and his dignity, social justice, equity, tolerance, respect for the basic rights and needs of others, freedom of self expression and participation, commitment to purpose and meaning in human existence, fairness, loyalty and commitment to human, personal and societal ideals, tolerance and acceptance of individual differences, and ideal of being each other's brother's keeper (Indabawa \& Mpofu, 2006; Fagerlind \& Saha, 1989; Okediji, 1981; Okorosaye-Orubite, 2005; Akinpelu, 2002). It is a change in the structure and ideology of a given society (Okeem, 1987).

\subsection{Political Dimension}

Political dimension comprises government services and resources, system of government, political representation and decision-making, international relations, national security, creation of national identity, creation of unity and solidarity among the people, mobilization for increased participation in voting, reading and analysis of political matters.

\section{Socio-Economic Development}

The concept of socio-economic development grew out of arguments that any growth in the economy must reflect on the well-being of the masses if such growth must be appreciated. For instance, Obi (1987) observes with dismay that many countries normally develop without growth due to overemphasis on economic growth as a yard stick for measuring development. This has resulted in what Callaway in Obi (1987:72) described as "growth in economic terms without development in the sense of improved conditions of living for the majority of the people. Again, development was achieved at the expense of the other needs of the people for whom development was meant". Bowles in Obi (1987) buttressed this point by lamenting over the concentration of planners on the establishment of infrastructure such as power plants, steel mills, refineries, railways, bridges, roads etc to the extent that they give an ominously low priority to the welfare of the under-privileged masses whose hopes and fears, satisfaction and frustration are keys not only to political stability but to the development process itself. Anyanwu (1987) joined to condemn developmental efforts from this perspective by arguing that capital investment, by itself, would achieve nothing for national consolidation if it did not have behind it the force of human skills. In his bit, Harbison in Obi (1987:75) maintains that "the wealth of a country is dependent not so much upon its natural resources and material capital; it is determined in a significant degree by the knowledge, skills and motivation of its people".

It is against this background that socio-economic development is defined as economic growth accompanied by social transformation of human beings and society. It is a growth in the economy which leads to the satisfaction of human needs for improved human well-being. This implies efficient and effective application of economic benefits of any growth to establish structures and institutions that enable human beings to acquire knowledge, attitudes and skills required to boost their self-confidence, creativity and readiness to participate in all 
issues involving their personal development and that of their society. Eheazu (1991) defines socio-economic development as it applies to rural dwellers to mean "a process of positive social and economic change which aims at raising the standard of living, quality of life, and the dignity of rural dwellers".

\subsection{Indices of Socio-Economic Development}

Socio-economic development manifests in the following ways:

1) improved standard of living;

2) improved levels of awareness;

3) improved production capacities;

4) transition from primary to secondary production;

5) improved infrastructural base;

6) good governance;

7) presence of basic amenities,

8) presence of improved social services, etc.

\subsection{Processes of Socio-Economic Development}

For socio-economic development to be achieved, the following among steps have to be followed:

1) provision of functional education;

2) transformation of the basic production processes;

3) provision of adequate infrastructure; and

4) provision of basic industrial technology.

\section{The Nigerian Factor: A Bane to Successful Socio-Economic Development}

The Nigerian factor is a slogan used to indicate the level of moral decadence and normalization of crime in Nigerian society. It is a situation whereby there is lack of interest in the production of goods and services by those it is entrusted in their hands but they would want to earn money to live. When it becomes necessary that the services must be rendered, gifts of any sort must exchange hands before anything happens. It also indicates a situation of lack of interest in the provision and maintenance of public facilities, and in most cases, when funds are provided for them; the funds are diverted into private purses. Sometimes, some of the public facilities are either converted into private use or allowed to dilapidate because they belong to nobody and nobody would care to protect and maintain them. This situation was borne from four different phenomena namely:

1) Squandermania mentality; 
2) Poor leadership selection process;

3) Contacts and connections (who do you know); and

4) Crave for paper certificates instead of real education.

\subsection{Squandermania Mentality}

This is a term used by Okolo (1994) to denote the 'acquisitive instinct' of a Nigerian whereby things are viewed by the people from the perspective of their consumable value. What makes sense and therefore worth striven for by individuals is conceived in terms of its material worth and advantage. Individual relationship to one another particularly to the nation is also seen from that materialistic perspective. The results in the quest for wealth accumulation and display, occupations of instant gain, fraudulent practices aimed at making more and more money. According to Okolo, it is this mentality that makes people to rejoice when their own man is made a minister, commissioner, board member, etc not because they hope to share his salary with him but because they expect him to play his card well, to give employment to some of their unemployed youths, to give them contracts, scholarships, honour their launching invitations, etc and if after relinquishing his office he fails to erect for himself a row of mansions, win some fleet of cars and maintain a healthy balance in the bank both in Nigeria and overseas, he shall be regarded as a failure.

\subsection{Poor Leadership Selection Process}

It is a public knowledge that politics- a process of selecting the leaders of the country has been seen as a quick means of wealth accumulation. Political power empowers the holders and their relatives and friends economically which invariably guarantees social influence to them. It is against this background that majority of Nigerians either want to acquire political positions or be closer to those holding political positions. This makes the political system to be fraught with a lot of malpractices such as rigging, violence, killings and rituals because when the power is acquired, wealth accumulation is guaranteed. The wealth is acquired through looting, conversion of public property to a private one, 'appreciation and understanding' in the Nigerian context, 10 percent kick-backs on award of contracts, inflation of contract worth etc.

\subsection{Contacts and Connections (Who do you Know?)}

This is a condition whereby people are either holding a public position of trust (in politics or civil service) or are closely related to those holding the positions. The result of this is people becoming billionaires overnight without questions being raised. This is the cause of the emergence overnight of politicians without pedigree, crude oil merchants without oil companies, briefcase contractors and suppliers without cognate companies or even a room apartment as an operational office.

\subsection{Crave for Paper Certificate Instead of Real Education}

Education in Nigeria is conceived in terms of material gain. Knowledge for its own sake or for higher goals such as pleasure, for widening of one's perspectives, understanding one's 
world or happenings in the universe, or even for a much more acknowledged functional use of education, namely, the development of worthwhile skills to profit society and posterity is usually a distant dream. The people are concerned not with qualitative functional education which should really help them master and transform their environment but with certificate education which guarantees them positions of influence in the society (Okolo, 1994). This situation has given birth to students who are not scholarly inclined but would want to collect certificate and a good one indeed and leave the university system. Ills associated with this phenomenon are examination malpractices resulting to watering down of the quality of education in the country.

The phenomena highlighted above have led to the collapse of the country's socio-economic foundation and hence, the collapse of infrastructural base (power, roads, railways, airports, seaports etc), and dilapidation of public hospitals, health centres and public educational institutions (Okowa, 2005). Okowa (2005: 41-49) also identified factors proved to be responsible for the collapse of Nigeria's socio-economic formation. They are among others:

Dependence on foreign technology, monocultural dependence on crude oil, dependence on the foreign sector for raw materials and spares, inadequate supply of skilled labour, low productivity and low per capita income, underdeveloped agriculture, high rate of unemployment, inegalitarian distribution of income and wealth, high rate of inflation and interest rates, excessive government involvement in the economy, heavy external debt burden, poor attitude to work, particularly in the public sector, systemic corruption, high population rate of growth, limited autonomization of the state, lack of democratic norms, strong tendencies towards ethnicity and religious bigotry, impure and inequitable federalism, institutionalization of political prostitution, collapse of the moral base, normalization of crime, and collapse of the culture of respect for the rule of law.

These factors contrast with the government's recent announcement of the growth of GDP to 80.3 Trillion Naira. This is expected because, when everybody is inclined towards grabbing the nation's common wealth, we end up having nothing for everybody to grab and enjoy because the pieces of the wealth that could have been harnessed for meaningful development to occur would be destroyed through the 'scramble and partition mentality' of the people. This mentality is anthropocentric in nature. It is the root cause of social ills in the nation such as systemic corruption, armed robbery, kidnapping, militancy, terrorism, illegal oil bunkering and public property vandalism.

These vices are cog in the wheel of development and as a result lead to further under-development of the nation because of the stagnation of the systems and structures which drive development. In this case, the GNP, GDP and Per Capita Income of the nation dwindle leading to the inability of the leadership of the nation to provide social services and develop infrastructural facilities that could make life comfortable for the citizens. The multiplier effects of this phenomenon include increase in the rates of poverty, illiteracy, mortality and natality, prostitution, human trafficking and child labour, drug abuse and trafficking, electoral malpractices and violence which further plunges the nation into serious socio-economic doldrums. This situation signals the relevance of adult education as an 
instrument of social reconstruction to forestall this phenomenon as well as develop a literate, informed, skilled and healthy adult population which is a pre-requisite for meaningful socio-economic development.

\section{Adult Education Programmes for Promotion of Socio-Economic Development}

It has been noted earlier that humans especially adults hold the destiny of any nation in their hands because they are those who are already working and participating in development efforts. Adults have been considered both as assets and capital for productive efforts. It is therefore necessary to develop them for they are the procurers and the beneficiaries and protectors of economic growth. They are the primary voters, consumers, workers, teachers, scientists and parents of today (Guerava, Flower, \& Whelan, 2003; Campbell in Obi, 1987). This view makes necessary the following adult education programmes for the development of literate, informed, skilled and healthy adult population for a meaningful socio-economic development. Such programmes relevant for the development of knowledge, skills, attitudes, values, motivation and commitment required for productive efforts include literacy education, civic adult education, vocational adult education and health adult education.

\subsection{Literacy Education}

Since the ultimate aim of development is to make it possible for people to have a better life and development cannot occur when a vast majority of a nation's citizens is illiterate because a literacy rate of 70 to 80 percent is required to trigger and sustain industrialization and rapid economic expansion to occur, literacy education is needed to inculcate in individual adults the relevant knowledge, skills, attitudes and values required to engage in productive efforts (United Nations, 1980; Goshi, 1974; Bowman \& Anderson in Fagerlind \& Saha, 1989).

Scholars have argued that literacy is pluralistic in the sense that it is of different types but Akinpelu (2002) identified alphabetic literacy as the most fundamental foundation and tool for all forms of worthwhile and sustainable development. He holds this type of literacy supreme on account that it is the inevitable foundation for most other forms or types of literacy and other types of literacy can only be genuine, authentic and sustainable if based on alphabetic literacy. Goshi (1974) maintains that literacy is a pre-requisite for social change and progress and as well leads to the acquisition of vocational knowledge and technical skills required for economic development. Aderinoye (2004) sees literacy as a catalyst for participation in social, cultural, political and economic activities and for learning throughout life.

Literacy in all its forms of existence as alphabetic, technological, computer, environmental, scientific, financial, mathematical, health etc is a pre-condition for meaningful socio-economic development to occur. Literacy provides people with the opportunity and foundation to acquire the knowledge and understanding of their civic rights and responsibilities, knowledge of health tips to live healthy, technical and vocational skills to drive the economy and the right types of attitudes, norms, values, morals required for a society to progress in the positive direction. Venn (1970) provides that adult education through its literacy programme develops in adults reading and writing skills to aid them in 
undertaking training in the basic skills of some semi-skilled occupations. Therefore, literacy education and other types of education which provide opportunities for the development of other forms of literacies should be given priority attention.

\subsection{Civic Adult Education}

Miller (1970) sees civic adult education as education for public responsibility which seeks to mainstream people into public service and as well empower them to contribute inputs of time, energy and money in order to receive diverse outputs of goods, services and cultural satisfactions and this is achieved through participation in economic, religious, political, educational and public service organizations. It is education for social and public responsibility which reflects programmes designed to develop understanding and knowledge of the public issues and problems facing any nation and its citizens domestically and internationally in political, economic and social areas (Power, 1970). Anyanwu (1987) sees civic adult education as fundamental adult education concerned with teaching the fundamental techniques of life arising as a result of rapidity in social changes, and the consequent necessity for adaptation to change. According to him, it deals with the problems of social or community development, and is concerned also with the introduction of new ideas, skills and techniques, new ways of thinking and new methods of organization.

The collapse of the socio-economic formation of the country which gave rise to a far-reaching turbulence in the fabric of Nigerian society underscores the need for civic adult education for value re-orientation that recognizes that:

1) Wealth is created through a productive effort;

2) The fundamental objective for the acquisition of political power is service to the community; and

3) The need for general acceptance of the rule of law.

4) This form of value re-orientation promotes the maintenance of the tripod framework for socio-economic formation of Okowa (2005).

\subsection{Vocational Adult Education}

Venn (1970) defines vocational education as "a process of developing the adult individuals for social, economic and occupational competence". That is, it is a process of preparing adults for entrance into the world of work. He sees it as a process because he emphasized that "while the simple entry-level job skills acquired by a worker are helpful, the setting into which the individual will carry out these skills, once he is on-the-job, is frequently so complicated that additional coaching and consultation must be given him by those who would provide sound vocation-technical education". Anyanwu (1987) sees vocational adult education as occupational education which caters for the acquisition of more efficient skills and techniques required to up-grade those in regular employment, and those who wish to become more proficient in their vocations. In emphasizing the relevance of vocational adult education, Anyanwu stresses that the development of agriculture, the growth of the organization and the evolution of new forms of trade and commerce necessitates the 
organization of training programmes and refresher courses to enable the recipients to update their knowledge and skills, learn new techniques and new types of organizational methods in order to improve their efficiency.

In most cases, such education tends to enable workers to read better, to understand the implications of current social and political problems, and to appreciate the changes in their society. It often takes the forms of apprenticeship to provide the recipients with basic skills for some semi-skilled occupations; in-service training programmes to update their skills; on-the-job training to increase their efficiency and prepares recipients for the next higher level of employment. Sometimes, it helps to prepare the recipients for employment in completely new fields where they feel better adapted for the development of what is best in them and in the execution of their occupational tasks. Vocational adult education develops skilled and semi-skilled manpower in both the formal and informal economy required for substantial economic growth and development.

\subsection{Health Adult Education}

No unhealthy society can be productive. Health according to World health Organization (WHO) in Ekpu (2007) is "a state of complete physical, mental and social well-being and not merely the absence of disease and infirmity". The need for a healthy nation for increased and improved socio-economic development calls for a type of education which increases peoples' knowledge, skills, inclinations and chances of success in changing their behaviours so that it will be compatible with the demands of good health (Ekpu, 2007). Health education planned for the adult population aims not only to expose adults to behaviours and life styles choices which constitute health risks and empowers them with new knowledge, skills and techniques to identify them in any given environment (home and workplace) as well as avoid them. Health adult education exposes adults to healthy behaviours, life style choices and practices which will enable them to remain productive for sustained socio-economic development.

\section{Problems of Adult Education in Nigeria}

Adult education encounters a lot of problems that hampers it from assuming its position as an effective tool for socio-economic development in Nigeria. Among these problems are:

1) Misconception of the principles and desirability of adult education in the society: Adult education has been misconceived to mean a 'night school' meant for old men and women that are about to die. This misconception questions its desirability and effectiveness in driving the socio-economic development activities of the country.

2) Illiteracy: This is a problem faced by adult education in Nigeria. The rural dwellers who have the highest population of illiterate adults do not know the importance of education and cannot afford to buy some instructional materials. Most adults still believe that, you cannot teach an old dog a new trick. This means that an adult cannot learn a new thing.

3) Lack of political will: Institutional frameworks for the implementation of adult education programmes have been provided. But the will to match the declarations in 
the frameworks with actions is lacking. This may be because political leaders lack understanding of the relevance of adult education to national development or they tactically do not want a vast majority of adults to be educated in order not to be empowered to start asking questions about how the nation's affairs are run.

4) Poor budgetary provision: Education generally is poorly budgeted for in Nigeria's annual budget. This invariably affects adult education as an arm of education. UNESCO recommends that $26 \%$ of every nation's annual budget should be dedicated to education while Global Campaign for Education (GCE) recommends that not less than $3 \%$ of every nation's annual budget for education should be dedicated to adult education. But the highest Nigeria has got in terms of budgetary allocation to education was $10 \%$ in the year 2012. Both UNESCO's and GCE's recommendations have not been met either for education or adult education.

5) Lack of infrastructure: Infrastructure to implement adult education programmes is lacking due to paucity of fund. This either hampers progress in the achievement of the objectives of adult education programmes or leads to closure of many adult education centres.

6) Lack of instructional materials: This has led to the use of instructional materials meant for children in the formal school sector and hence, adult learners are discouraged from active participation in their learning programmes. This is because most of them see themselves as been reduced to the status of the children those materials were designed for.

7) Lack of trained personnel: There is paucity of trained personnel for the implementation of adult education programmes in Nigeria. Many people plying the business of adult education in Nigeria are not trained in the principles, theories and practices of adult education and thereby may not help to realize the objectives of adult education in Nigeria.

8) Socio-cultural factors: traditional social structures that exist in a given society may lead to either acceptance or rejection of any adult education programmes that are planned to be introduced in that society. The fear that the programmes may lead to disruption of social relations, loss of traditional knowledge, norms, values, and customs will result in the rejection of the programmes. Whereas the hope of positive change and development that will accompany the programmes will result in the acceptance of the programmes; and

9) Adult learners' self concept: The feeling that adults can participate and perform better in a programme results in increase in participation and better performance of learners in any given adult education programmes. Whereas the feeling that the programme is not for adults and even when they participate, would not perform better, results in low turn-out and poor performance of learners in any given adult education programmes. 


\section{Conclusion}

Adult Education is portrayed in this work as a veritable tool for socio-economic development in Nigeria. This is owed to the fact that adult education has programmes designed for adults who constitute up to $55 \%$ of Nigeria's population and who are also the economically productive and active citizens. The irony is that majority of the illiterates in the country are located within this category of citizens. It is this category of citizens that relevant adult education programmes are designed to equip with relevant knowledge, attitudes, skills and commitment required to drive meaningful socio-economic development in Nigeria. It is on this background that adult education programmes are designed to identify and forestall problems which form a cog in the wheel of development by developing a literate, informed, skilled and healthy adult population which is a pre-requisite for meaningful socio-economic development.

\section{References}

Aderinoye, R. A. (2004). Literacy education in Nigeria. Ibadan, Nigeria: University Press.

Akinpelu, J. A. (2002). Philosophy \& adult education. Ibadan, Nigeria: Stirling-Horden Publishers.

Anyanwu, C. N. (1987). Developing adult education in Nigeria. Ibadan, Nigeria: University Press Limited.

Barikor, C. N. (2002). Principles and practices of adult and non-formal education. In J. M. Kosemani (Ed.), Introduction to education. Port Harcourt: Shapea Publishers.

Bown, L., \& Tomori, S. H. O. (1979). Handbook of adult education for West Africa. London: Hutchinson \& Co.

Eheazu, B. A. (1991). Adult education and the socio-economic development of Nigeria's rural areas. In J. I. Mereni (Ed.), Adult education and rural transformation (pp. 138-145). Enugu, Nigeria: Asomog Publishing Coy.

Eheazu, B. A. (1998). The right to learn: Relevance of adult education. University of Port Harcourt Inaugural Lecture Series No 20.

Ekpu, F. S. (2007). Environmental education and sustainable health. In E. N. Etuk, I. M. Udofot \& A. E. Udosen (Eds.), Education in Nigeria in the $21^{\text {st }}$ century: Focus \& Imperatives (pp. 235-246). Uyo, Nigeria: Abaam Publishing Co.

Ezimah, M. O. A. (2004). Knowing adult education, its nature, scope and processes. Owerri: Springfield.

Fagerlind, I., \& Saha, L. J. (1989). Education and national development: A comparative perspective. Oxford, Britain: Pergamon Press.

Goshi, A. Y. (1974). Programming adult literacy for community development in Nigeria. In J. T. Okedara \& R. Stanford (Eds.), The role of adult education in Community development (pp 150-157). Ibadan, Nigeria: Nigerian National council for adult Education. 
Guerava, J. R., Flower, R., \& Whelan, J. (2003). Popular and informal environmental education: The need for more research in an emerging field of practice. Unpublished Manuscript.

Hall, B. L. (1981). Mass communication and adult education. In L. Bown \& J. T. Okedara (Eds.), An introduction to the study of adult education: A multi-disciplinary and cross-cultural approach for developing countries (pp. 215-231). Ibadan, Nigeria: University Press.

Indabawa, S., \& Mpofu, S. (2006). African perspective on adult learning: The social context of adult learning in Africa. UNESCO Institute for Education

Mbalisi, O. F. (2010). Effectiveness of environmental education in the development of responsible environmental behavior among adult learners in Rivers State. Doctoral Dissertation, University of Port Harcourt.

Miller, P. A. (1970). A glance at the future. In R. M. Smith, G. F. Aker \& J. R. Kidd (Eds.), Handbook of adult education (pp. 151-167). New York, USA: MacMillan Publishing Co.

Nnazor, R. (2005). Adult education in Nigeria: The consequence of neglect and agenda for action. International Education Journal, 6(4), 530-536.

Nzeneri, I. S. (2008). Handbook on adult education: Principles and practices (new ed.). Uyo: Abigab Associate.

Obi, C. O. (1987). The emerging concept of development and adult education. In F. C. Okafor, E. O. Okeem \& J. I. Mereni (Eds.), Foundations of adult education (pp. 71-83). Obosi-Anambra, Nigeria: Pacific Publishers

Okediji, F. O. (1981). Sociology, demography and adult education. In L. Bown \& J. T. Okedara (Eds.), An introduction to the study of adult education: A multi-disciplinary and cross-cultural approach for developing countries (pp. 114-120). Ibadan, Nigeria: University Press.

Okeem, E. O. (1987). Social structure, ideology and adult education. In F. C. Okafor, E. O. Okeem \& J. I. Mereni (Eds.), Foundations of adult education (pp. 49-54). Obosi-Anambra, Nigeria: Pacific Publishers.

Okolo, B. C. (1994). Squandermania mentality: Reflections on Nigerian culture. Nsukka-Enugu, Nigeria: University Trust Publishers.

Okorosaye-Orubite, A. K. (2005). Education and development. In O. G. Agabi, A. K. Orubite, J. Ezekiel-Hart \& D. E. Egdezor (Eds.), School \& society, (pp. 18-51). Port Harcourt, Nigeria: Davidstones.

Okowa, W. J. (2005). Oil, "Babylonian" "matthewnomics" and Nigerian development. University of Port Harcourt Inaugural Lecture Series No 40.

Power, H. (1970). Education for social and public responsibility. In R. M. Smith, G. F. Aker \& J. R. Kidd (Eds) Handbook of adult education (pp. 457-471). New York, USA: MacMillan 
Publishing Co.

Schroeder, W. L. (1970). Adult education defined and described. In R. M. Smith, G. F. Aker \& J. R. Kidd (Eds.), Handbook of adult education (pp. 25-43). New York, USA: MacMillan Publishing Co. http://dx.doi.org/10.1177/074171367002000409

United Nations. (1980). Interrelations, resources, environemt, population and development. Proceedings of a United Nations Symposium held at Stockholm from 6-10 August, 1979.

Venn, G. (1970). Vocational-Technical education. In R. M. Smith, G. F. Aker \& J. R. Kidd (Eds.), Handbook of adult education (pp. 473-486). New York, USA: MacMillan Publishing Co.

\section{Copyright Disclaimer}

Copyright reserved by the author(s).

This article is an open-access article distributed under the terms and conditions of the Creative Commons Attribution license (http://creativecommons.org/licenses/by/3.0/). 